\title{
A Study on the Sense of Understanding in Terms of Existentialism
}

\author{
Shao-hua ZHANG \\ School of Foreign Languages, Henan Institute of Engineering, Zhengzhou, China \\ 32453091@163.com
}

Keywords: Investigation, Dasein, Sense of understanding, Existentialism, State-ofmind.

\begin{abstract}
Understanding and state-of-mind must inevitably have their basis of the lifeworld, the world of "being-in-the-world". As a state-of-mind, understanding is not a transcendental apprehension or comprehension as a gift given by God; it is constructed in the being-in-the-world, formed in a fabric of relationships of the lifeworld. Based upon this being-in-the-world, understanding in its everyday life, proximally and for the most part, does not know the distinction between cognitive subject and cognized objects. An understanding in Heideggerian sense is not necessarily explicit, definite, specific, or thematic. "One determines the nature of entities in their Being without necessarily having the explicit concept of the meaning (understanding; added) of Being at one's disposal. Otherwise there could have been no ontological knowledge heretofore" (BT, 27). However, this character of an understanding has already played the function of leadership to the being of entities.
\end{abstract}

\section{Introduction}

Dasein or the human being has "understanding" and "state-of-mind" as its co-original constituents. Dasein essentially consists in its existence which is determined by its existing, by its 'to be', by its Being-possible. Therefore, understanding and state-of-mind again are the constitutive items of Dasein's or the human being's existing. Understanding and state-of-mind must inevitably have their basis of the lifeworld, the world of "being-in-the-world". As a state-of-mind, understanding is not a transcendental apprehension or comprehension as a gift given by God; it is constructed in the being-in-the-world, formed in a fabric of relationships of the lifeworld. Based upon this being-in-the-world, understanding in its everyday life, proximally and for the most part, does not know the distinction between cognitive subject and cognized objects. Understanding is the production of inter-action and inter-edification between Dasein or the human being as a being and other entities as beings. That Dasein understands the being of entities in some state-of-mind may happen in a very natural, inconspicuous, unpremeditated, and unthematic way, because "however much this understanding of Being (some understanding which is already available to us; added) may fluctuate and grow dim, and border on mere acquaintance with a word, its very indefiniteness is itself a positive phenomenon" (BT, 25). Examples may be seen in effortless utterances like: The sky is blue. I am merry. They are dogs, etc. So an understanding in Heideggerian sense is not necessarily explicit, definite, specific, or thematic. "One determines the nature of entities in their Being without necessarily having the explicit concept of the meaning (understanding; added) ofBeing at one's disposal. Otherwise there could have been no ontological knowledge heretofore" (BT, 27). However, this character of an understanding has already played the function of leadership to the being of entities. To further our thinking along this line, we will 
become more and more clear about the ontological function of Heideggerian sense of an understanding.

\section{Understanding as an Ontological Conception}

To make a distinction between being and beings by proposing the fundamental ontology will be at the same time to make a similar dichotomy between the transcendental and the empirical. By the almost fixed expression of "understanding of Being" and the "11 indications" of the word "of' (See pages 39-40) in such an expression, we have been inducted to this recognition that "understanding" has the same status as that of "being". When we ask the question "What are the beings?" we are in fact asking "What is the Being of entities?" or "What are the entities being asked about thereby?" The first question is "about beings as such", the second question is "about Beings as a whole" (EB, 220/150). It is the wholeness or totality of the whole beings or entities that unifies and generalizes themselves, provides the ground to bring them forth, to let them stand out in themselves, in terms of their being. The moment when we ask the question about the meaning of being is literally the time when ask the understanding of being, and vice versa. For the meaning is made by no other means than an understanding. An understanding always means "an understanding of meaning" just as it always means "an understanding of being", even though we can say that an understanding means "an understanding of something", because the meaning in its existential sense means "upon-which" which is achieved in the projection of an understanding, therefore the latter expression is the compressed form of "an understanding the meaning of something which has already been understood as such". Here, we see that understanding, being, and meaning have a close intrinsic relationship among them. An understanding always corresponds with its meaning. When an understanding is accomplished, it always means something like meaning is gained. In this sense, we can say "understanding" is a success verb, where there is an understanding there is meaning, even though the meaning as the understanding itself may be vague, indefinite, or unthematic.

In Bing and Time, Heidegger more often than not uses the expression of "understanding of Being", but he also uses the expression of "understanding of the meaning of Being" when needed. It is the opinion of the author of this paper that the two expressions are the same. So, here "understanding", "meaning", and "Being" are alike treated on the same level of ontology in Heidegger's existential-ontological analysis of Dasein. As is well-known, Being in the Western philosophy is the highest category, the most comprehensive genus, "the most general of generalities" (BT, 29), but in Heidegger's hermeneutic phenomenology, Being has been therefrom restituted to its genuinely ownmost itself: it has been rescued from categorial beings and has been restored to the most basic concept of existence. Thus 'being" in Heidegger's hermeneutic phenomenology does not mean an entity any longer but means the being of entities, and hence entities are determined by their being. That is why we have a being or beings to refer to an entity or entities. Being is not an entity yet it cannot leave away from entities in its existential-ontological anatomy, it is the universal name for all entities which are encountered in our understanding in the world. Accordingly, if we want to add more to the foregoing characters of being, such an expression is the most proximal, the most preferential choice: "the most ontological of ontologies" and this kind of ontology can but be the being-ontology. Therefore, the "understanding" of the expression "understanding of being" can only be the most basic, the most ontological understanding of all understandings. 


\section{Understanding Taking Place before Which Comporting Towards}

Furthermore, because anything towards which Dasein comports itself must be understood with an understanding (of being) beforehand, so, in essence an understanding itself functions as a lamp which supplies an intelligible light to illumine both Dasein and the things simultaneously. Even being - the most basic existential concept - must be enlightened with understanding the moment it is understood as such. More strictly, if and only if there is an understanding is there a being. "In BT being depends on our understanding of it: 'Beings are, independently of experience, acquaintance and grasping, by which they are disclosed, discovered and determined. But being 'is' only in the understanding of the beings whose being involves such a thing as understanding of being. Being can therefore be uncomprehended, but it is always to some extent understood" ( $\mathrm{HD}, 236$ ). In short, the fundamentally ontological understanding just functions as the competence which is able to get anything encountered by Dasein within-the-world. Even when we casually utter a sentence "The sky is blue", an understanding of being has already been there. For the utterance of this simple sentence indicates our competence of uttering it. "Understanding is the existential Being of Dasein's own potentiality-for-Being; and it is so in such a way that this Being discloses in itself what its Being is capable of' (BT, 184).

We should be clear about the distinction between the ontological understanding and the ontical understanding of something if we do not want to be confused by such expression as "understanding of something" when understanding is lowered down or lifted up to the empirical level. "On the other hand, 'understanding' in the sense of one possible kind of cognizing among others (as distinguished, for instance, from 'explaining'), must, like explaining, be interpreted as an existential derivative of that primary understanding which is one of the constituents of the Being of the 'there' in general' (BT, 182). At this point, Palmer (1969) concludes, 'Understanding is conceived not as something to be possessed but rather as a mode or constituent element of being-in-the-world. It is not an entity in the world but rather the structure in being which makes possible the actual exercise of understanding on an empirical level. Understanding is the basis for all interpretation; it is co-original with one's existing and is present in every act of interpretation. Understanding is thus ontologically fundamental and prior to every act of existing" (Palmer, 1969: 131). In this sense, understanding not only encompasses our existence completely but also directs our every act of existing. Next, we are going to talk about this encompassing structure of understanding.

\section{Understanding as a Holistic Structure}

What, then, is an understanding of all understandings? As Heidegger uses the term, an understanding is nothing necessarily cognitive, but rather the entire or total scope of our ability to make sense of anything by availing ourselves of them, even if unreflectively, in practice. An understanding means competence, skill, and know-how: "In speaking ontically, we sometimes use the expression 'to understand something' in the sense of 'managing an affair', 'being up to it', 'being able to"' (BT, 143). Whereas traditional epistemology assumes that human understanding as an entity or something possessed which essentially amounts to cognition, the theoretical grasp of propositions, Heidegger instead construes it as the practical ability, as a mode of existing. Heidegger, therefore, rejects traditional conceptions of understanding in favor of the more familiar common notion drawn from ordinary language: "understanding oneself in the being of one's ownmost ability to be is the primordial existential concept of 
understanding. Its terminological meaning goes back to common linguistic usage, when we say: someone can manage a thing, i.e. he has an understanding of it" (GP, 391-2, cited from HA, 19).

Therefore, Heideggerian sense of understanding, as observed above, is not in the empirical, ontical sense, but in the transcendental, ontological one; it is not a particular application or some concrete ability of intelligence or intelligibility, but is an overarching form or structure which gives a steady light to the various applications of it, that is, to understand something is based upon that constitutive primary understanding. The time when Heidegger makes the ontological difference (that is, the distinction between being and beings) is in fact the time when he endows being with priorities over beings. Being, co-existing with understanding arises out of an understanding of being of entities. This kind of being of entities in itself brings forth entities which we encounter within-the-world in the very way in which it lets the entities show themselves from themselves; it is the most primordial understanding of being that constructs entities and gets entities into order, into meaningfulness. As Lafont (2000) points out, "The ontological difference (the distinction between being and beings; added) is established in such a way that it follows that there can be no access to entities without a prior understanding of their being. It is for this reason that entities appear to us as always already understood in one way or another (as thus or thus), or, as Heidegger puts it, why 'we always already move about in an understanding of being" " (HW, preface: xiii).

\section{Conclusion}

But "Being is always the Being of an entity" (BT, 29), thus we not only always move about in an understanding of being but also in an understanding of entities (entities include human kinds). So, the world of entities in which we are is no longer ontically 'the totality of those entities which can be present-at-hand within the world" (BT, 93), but on the contrary, it is a world which designates "the ontological-existential concept of worldhood. Worldhood itself may have as its modes whatever structural wholes any special 'world' may have at the time; but it embraces in itself the a priori character of worldhood in general" (ibid). That is to say, the world of entities in the existential-ontological sense is such a world which has not only been illumined by an understanding of being but also arranged in such-and-such a mode thereby. In this sense, 'the world is not an entity within-the-world; and yet it is so determinative for such entities that only in so far as 'there is' a world can they be encountered and show themselves, in their Being, as entities which have been discovered" (BT, 102). Based upon Heidegger's ontological-existential analysis of the "world", the "world" is a world made up of understanding of being of entities in terms of being-structure. Yet considering "Being is always the Being of an entity", so this conceptual world, or the world illumined by an understanding of being or worldhood, is not independent of the ontical-existentiel world which is the ground in which the ontological-existential concept of worldhood finally lies.

\section{References}

[1] Heidegger, Martin. "Being and Time: Introduction" in Martin Heidegger: Basic Writings, David Farrell Krell (ed. \& trans.) London: Harper Collins Publisher, Inc., 1993.

[2] Heidegger, Martin. Being and Time. John Macquarrie \& Edward Robinson (trans.) China Social Sciences Publishing House Chengchengh Books Ltd., 1999. 
[3] Holdcroft, David. Saussure: Signs, System, and Arbitrariness. New York: Cambridge University Press, 1991.

[4] Holmes, James S. Translated! Papers on Literary and Translation Studies. Beijing: Foreign Language Teaching and Research Press, 2007. 